\title{
Dm3 Is One Member of a Large Constitutively Expressed Family of Nucleotide Binding Site-Leucine-Rich Repeat Encoding Genes
}

\author{
Katherine A. Shen, Doris B. Chin, Rosa Arroyo-Garcia, Oswaldo E. Ochoa, Dean O. Lavelle, Tadeusz \\ Wroblewski, Blake C. Meyers, and Richard W. Michelmore
}

Department of Vegetable Crops, University of California, Davis 95616, U.S.A.

Submitted 28 September 2001. Accepted 29 November 2001.

The major cluster of resistance genes in lettuce cv. Diana contains approximately 32 nucleotide binding site-leucinerich repeat encoding genes. Previous molecular dissection of this complex region had identified a large gene, $R G C 2 B$, as a candidate for encoding the downy mildew resistance gene, Dm3. This article describes genetic and transgenic complementation data that demonstrated $R G C 2 B$ is necessary and sufficient to confer resistance with $\mathrm{Dm} 3$ specificity. Ethylmethanesulphonate was used to induce mutations to downy mildew susceptibility in cv. Diana $(\mathrm{Dm} 1, \mathrm{Dm} 3$, $D m 7$, and $D m 8$ ). Nineteen families were identified with a complete loss of resistance in one of the four resistance specificities. Sequencing revealed a variety of point mutations in $R G C 2 B$ in the six $d m 3$ mutants. Losses of resistance were due to single changes in amino acid sequence or a change in an intron splice site. These mutations did not cluster in any particular region of $R G C 2 B$. A full-length genomic copy of $R G C 2 B$ was isolated from a lambdaphage library and introduced into two genotypes of lettuce. Transgenics expressing $R G C 2 B$ exhibited resistance to all isolates expressing $A v r 3$ from a wide range of geographical origins. In a wildtype $D m 3$-expressing genotype, many of the $R G C 2$ family members are expressed at low levels throughout the plant.

Disease resistance in plants often is initiated by a specific gene-for-gene interaction between the products of single dominant genes in the plant and corresponding avirulence genes from the pathogen. Genetic and molecular analyses show that such disease resistance genes are frequently clustered in plant genomes (Ellis et al. 2000; Hulbert et al. 2001; Michelmore and Meyers 1998). In lettuce, classical genetic analysis has identified over 15 genes conferring resistance to downy mildew ( $D m$ genes) that provide resistance to specific isolates of the obligate oomycete pathogen Bremia lactucae in a gene-for-

Corresponding author: R. W. Michelmore, Telephone: 530-752-1729; Fax: 530-752-9569; E-mail: rwmichelmore@ ucdavis.edu

Current address of D. B. Chin: The Tech Museum of Innovation, San Jose, CA 95113, U.S.A.

Current address of R. Arroyo-Garcia: Dpto de Genética Molecular de Plantas, CNB-CSIC, Campus UAM, Cantoblanco, 28049 Madrid, Spain.

The first two authors should be considered joint first authors.

Nucleotide sequence data reported for $R G C 2 B$ are available in the Genbank database under the accession number AF072267. gene manner (Crute and Johnson 1976; Farrara et al. 1987; Ilott et al. 1989; Johnson et al. 1978). These Dm genes map to at least three major clusters (Bonnier et al. 1994; Farrara et al. 1987; Kesseli et al. 1994; Witsenboer et al. 1995). More than 10 resistance specificities genetically mapped to the largest cluster (the $D m 1 / 3$ cluster). Numerous markers have been identified that are unique to the region and tightly linked genetically to Dm3; however, the majority of these markers are duplicated in the vicinity of Dm3 (Anderson et al. 1996; Meyers et al. 1998a,b; Okubara et al. 1997). The complex nature of the locus has complicated positional cloning of $\mathrm{Dm}$ genes from this region of the lettuce genome (Meyers et al. 1998a,b).

Over 20 plant disease resistance genes ( $R$ genes) from a variety of plant species have now been cloned (Baker et al. 1997; Hammond-Kosack and Jones 1997; Jones 2001; Meyers et al. 1999). Most of these genes encode proteins characterized by a putative nucleotide binding site (NBS) and a leucine-rich repeat (LRR) region and determine resistance against a wide range of pathogens that include bacteria, fungi, oomycetes, viruses, nematodes, and insects. The conserved structural features encoded by $R$ genes suggest a limited number of signaling pathways in $R$ gene-mediated plant defense (Feys and Parker 2000; Glazebrook 1999). Conserved motifs within the NBS have allowed the isolation of candidate resistance genes from numerous plant species using polymerase chain reaction (PCR) with degenerate primers (Aarts et al. 1998; Graham et al. 2000; Kanazin et al. 1996; Leister et al. 1996; Meyers et al. 1999; Shen et al. 1998; Speulman et al. 1998; Yu et al. 1996). Several multigene families of resistance gene candidate $(R G C)$ sequences have been identified in lettuce, one of which was clustered at the $D m 3$ locus (the $R G C 2$ family) (Shen et al. 1998). Over $24 R G C 2$ family members were characterized from bacterial artificial chromosome (BAC) clones spanning a minimum of $3.5 \mathrm{Mb}$ at the Dm3 locus (Meyers et al. 1998a,b). Approximately $32 R G C 2$ family members are now known to be present in the cv. Diana (Dm3) haplotype (H. Kuang and R. Michelmore, unpublished data).

A variety of mutagens have been utilized to generate different types of mutations at several $\mathrm{Dm}$ loci in lettuce. Experiments investigating the potential of transposon tagging using the maize $A c$ transposase and $D s$ generated one transgenic mutant in which the loss of $D m 3$ specificity cosegregated with the T-DNA (Okubara et al. 1997). However, the low rate of $A c$ transposition in lettuce (Yang et al. 1993) indicated that mapbased cloning was likely to be a more successful approach to cloning Dm3. A panel of fast neutron (FN)-generated $D m$ mutants was generated and utilized to identify molecular markers closely linked to $\mathrm{Dm}$ genes, and to create a high-resolution de- 
letion breakpoint map of the Dm3 region (Anderson et al. 1996; Okubara et al. 1994). All FN-induced mutants had only a single specificity altered to a completely susceptible phenotype; each genetic lesion mapped to an individual $\mathrm{Dm}$ locus. Several of these mutants lacked flanking molecular markers and were therefore due to deletions at the respective $D m$ loci (Anderson et al. 1996; Meyers et al. 1998a; Okubara et al. 1994).

Allelism tests of the T-DNA and FN-induced $d m 3$ mutants indicated that $D m 3$ specificity was encoded by a single gene (Okubara et al. 1997). One member of the $R G C 2$ family was identified as a potential candidate for $D m 3$ based on genetic and molecular analyses of $d m 3$ mutants. $R G C 2 B$-specific markers, including the microsatellite marker MSAT15-34:1, were missing in a panel of nine FN-irradiated $d m 3$ deletion mutants (Meyers et al. 1998a; Okubara et al. 1997). Markers missing in all of the deletion mutants were present in a single BAC clone (BAC H15) containing $R G C 2 B$ (Meyers et al. 1998a; Okubara et al. 1997).

In this article, we report the genetic and molecular data that prove $R G C 2 B$ is necessary and sufficient to determine $D m 3$ specificity. Additional mutants were generated using the alkylating agent ethylmethanesulphonate (EMS) to favor the induction of point mutations at several $D m$ loci. Nineteen EMSinduced $\mathrm{Dm}$ mutants were isolated and characterized, including six with losses in Dm3 specificity. Sequence analyses revealed point mutations in the $R G C 2 B$ sequence of six independently isolated $d m 3$ mutants. Initial transformations with overlapping 11-, 16-, and 27-kb fragments derived from BAC $\mathrm{H} 15$ that contained the $R G C 2 B$ sequence had failed to confer resistance (Okubara et al. 1997). However, subsequent rapid amplification of cDNA ends (RACE) PCR analysis identified additional $3^{\prime}$ RACE products and revealed that $R G C 2$ genes were unusually large, encoding two long LRR regions, and that the copy of $R G C 2 B$ in BAC H15 was truncated. Therefore, a full-length copy of $R G C 2 B$ was isolated from a lambdaphage library and introduced into lettuce. Transgenics expressing the full-length $R G C 2 B$ gene conferred resistance with $D m 3$ specificity. In wildtype $D m 3$ haplotypes, the majority of $R G C 2$ family members are expressed at low levels throughout the plant.

\section{RESULTS}

\section{Identification of EMS mutants.}

EMS was used to induce mutations in several $D m$ resistance genes in the lettuce cv. Diana (Dm1, Dm3, Dm7, and Dm8). Primary inoculation of $\mathrm{M}_{2}$ lettuce seedlings with a mixture of four isolates of B. lactucae allowed easy and rapid identifica- tion of mutants with losses of resistance for each of the four $D m$ specificities present in wildtype Diana (Dm1, Dm3, Dm7, and $D m 8$ ) (Table 1). In all, 2,855 $\mathrm{M}_{2}$ families were screened for loss of activity at the four $\mathrm{Dm}$ resistance loci. The mutagenized plants exhibited a wide range of modified resistance phenotypes from profuse sporulation and no necrosis (complete losses of resistance) to extensive necrosis and minimal or no sporulation (partial losses of resistance). Over $70 \mathrm{M}_{2}$ families displayed necrotic phenotypes without sporulation. The high frequency of necrotic phenotypes indicated that many loci could contribute to this phenotype. Given the large number of necrotic families and the numerous disease lesion mimic loci known in other plant species (Dangl et al. 1996; Dietrich et al. 1994; Hu et al. 1996; Innes 1998; Johal et al. 1995; Richberg et al. 1998; Walbot et al. 1983), our efforts focused on mutants that displayed complete losses of resistance.

In all, 19 mutants exhibiting complete losses of resistance were identified from the primary inoculations of $2,855 \mathrm{M}_{2}$ families. Subsequent secondary inoculations with single isolates demonstrated the loss of only single $D m$ specificities in all mutants identified. Four of these mutants exhibited loss of Dml specificity (designated dm1e\#\#\# mutants), six mutants exhibited loss of $D m 3$ specificity (dm3e\#\#\#), six mutants had lost $D m 7$ specificity (dm7e\#\#\#), and three mutants had lost Dm8 specificity (dm8e\#\#\#) (Table 2 ).

Mutants lacking Dm3 activity were tested with four additional Avr3-expressing isolates that were from diverse geographical origins throughout the world (Table 1). All six dm $3 \mathrm{e}$ mutants were susceptible to these four isolates, confirming that the mutations had effected the loss of recognition in the Dm3/Avr3 interaction.

\section{Genetic analyses of Dm mutants.}

Segregation of resistance in the $\mathrm{M}_{2}$ and $\mathrm{M}_{3}$ generations was examined to analyze the inheritance and stability of the mutant phenotypes (Table 2). No significant deviations from a 3:1 ratio of resistant to susceptible seedlings were found in the $\mathrm{M}_{2}$ progeny. All $\mathrm{M}_{3}$ progeny, from three different susceptible individuals from each $\mathrm{M}_{2}$ family, were completely susceptible to the appropriate isolate of B. lactucae. Thus, in all the EMS-induced $d m$ mutants, susceptibility segregated as a recessive, stable trait at a single locus (Table 2). In parallel, to test for dominant mutations, mutants were backcrossed using wildtype Diana as the pollen source. Resistance was restored in the $F_{1}$ progeny of these crosses, confirming that all of the mutations were recessive (data not shown).

EMS mutants which exhibited a loss of specificity to the same isolate of B. lactucae were crossed to test for allelism. All $F_{1}$ progeny were susceptible for all crosses made within

Table 1. Virulence phenotypes of Bremia lactucae isolates

\begin{tabular}{|c|c|c|c|c|c|c|c|c|c|c|c|c|c|c|c|c|c|}
\hline \multirow[b]{2}{*}{ Isolate } & \multirow[b]{2}{*}{ Origin } & \multicolumn{16}{|c|}{ Reaction to $\mathrm{Dm}$ genes $^{\mathrm{a}}$} \\
\hline & & $\overline{D m^{\mathrm{b}}}$ & Dm1 & $D m 2$ & Dm3 & Dm4 & Dm6 & $\operatorname{Dm} 7$ & Dm8 & Dm10 & Dm11 & Dm12 & Dm13 & Dm14 & Dm15 & Dm16 & $\overline{D m 18}$ \\
\hline C83M47 & California & $D m 1$ & - & + & + & + & + & + & + & - & - & + & + & + & - & + & - \\
\hline IM25P11 & United Kingdom & $D m 3$ & + & - & - & + & + & + & + & + & + & + & + & + & + & + & - \\
\hline R60 & United Kingdom & Dm7 & + & + & + & + & + & - & + & + & + & + & + & + & + & + & - \\
\hline CG1 & Switzerland & Dm8 & + & - & + & + & - & + & - & + & - & + & + & - & + & + & - \\
\hline C96J504 & California & none & + & + & + & $(+)$ & + & + & + & + & + & + & + & + & + & + & - \\
\hline $\mathrm{AM}$ & Australia & $D m 3$ & + & - & - & $(+)$ & - & + & + & + & - & + & + & - & - & - & - \\
\hline IL4 & Israel & $D m 3$ & + & + & - & + & - & + & + & + & + & + & + & + & + & + & - \\
\hline C99S744 & California & $D m 3$ & + & + & - & + & + & + & + & + & + & + & + & + & + & + & - \\
\hline CG5 & Switzerland & $D m 3$ & + & + & - & + & - & + & + & + & - & + & + & + & - & $(+)$ & $(+)$ \\
\hline NL6 & Holland & $D m 3$ & + & + & - & + & - & - & + & + & + & + & + & + & - & + & - \\
\hline CS12 & Czechoslovakia & $D m 3$ & - & + & - & + & - & + & - & - & + & + & - & - & $(+)$ & + & - \\
\hline SF5 & Finland & $D m 3$ & - & + & - & + & - & - & - & + & - & + & + & + & + & - & - \\
\hline
\end{tabular}

$\overline{\mathrm{a}}+=$ profuse sporulation, $-=$ no sporulation, and $(+)=$ sparse sporulation.

b Diagnostic for $D m$ genes present in Diana. 
groups of $d m 1, d m 3, d m 7$, and $d m 8$ mutants (data not shown). EMS mutants also were crossed to a range of FN-irradiated mutants (Okubara et al. 1994) with the same losses of specificity. Again, all $F_{1}$ progeny were susceptible within specificity groups (data not shown). Thus, there was no evidence for intergenic complementation, implying that lesions had occurred in the same $D m$ gene for each specificity. To test for epistasis, mutants were crossed to Cobham Green, a closely related cultivar that contains no known functional $\mathrm{Dm}$ genes. Resistance was not restored in these crosses (data not shown), indicating that the mutations had not occurred in a locus that was epistatic to the $D m$ genes.

\section{Molecular analyses of $\mathrm{Dm}$ mutants.}

Flanking marker analysis. Mutants were assayed with molecular markers that are closely linked to each $D m$ gene cluster (Table 2) (Kesseli et al. 1994). The dm1e, dm7e, and dm8e mutants were analyzed for random amplified polymorphic DNA (RAPD) markers in each region. Of particular interest for the dm1e mutants were the RAPD markers $O P A B 16_{1700}$ and $O P B 19_{1200}$, which cosegregated with $D m 1$ in a mapping population of $245 \mathrm{~F}_{2}$ Calmar $(D m 7, D m 8$, and $D m 13) \times$ Kordaat (Dm1, Dm3, and Dm4) individuals (Anderson et al. 1996) and were absent in two FN-induced $d m 1$ mutants (Okubara et al. 1994). All markers screened were present in all these mutants, indicating that these mutations were not associated with detectable losses of chromosomal material.

As a result of our map-based cloning effort, a large number of markers were available for the $D m 3$ region. The six dm3e mutants were analyzed for nine RAPD markers, which all cosegregate with $D m 3$ in the mapping population (Table 2) (Anderson et al. 1996), two restriction fragment length polymorphism (RFLP) markers (IPCR ${ }_{800}$ and CL1795), and two microsatellite markers (MSAT15-34 and MSATE6). OPR14 and CL1795 represent sequences present in all of the FN-induced $d m 3$ mutants and denote the genetic boundaries of the deletions at approximately 1.8 and $2 \mathrm{cM}$ distant from $D m 3$, respectively (Okubara et al. 1994). Conversely, IPCR $R_{800}$, MSAT15-34, and MSATE6 represent sequences which are derived from the $R G C 2 B$ sequence (Fig. 1) (Meyers et al. 1998a; Okubara et al. 1994) and are thus tightly associated with the resistance phenotype. All 13 of these markers were present in the $d m 3$ EMS-induced mutants.
In addition to these markers, the dm3e mutants were analyzed using $R G C$ fingerprints. Primers were designed to amplify four 0.6 - to $1.3-\mathrm{kb}$ fragments that spanned the NBS- and LRR-encoding regions of $R G C 2 B$ (Fig. 1, Table 3) (Meyers et al. 1998a). Fingerprints of the EMS mutants were obtained by PCR from genomic DNA and subsequent digestion of amplification products with Tsp509I, MseI, or RsaI. Due to amplification from multiple family members, the fingerprints were complex but revealed no changes in the EMS-induced mutants in comparison to wildtype Diana (data not shown).

Cleavase fragment length polymorphism (CFLP) analysis. In order to gain greater resolution, $R G C$ amplification products were subjected to CFLP analysis, which detects point mutations and small insertions or deletions in DNA sequences (Brow et al. 1996). Several primer pairs were tested, but only the primer pair RLG2B5-1 and 5RACE3A (Fig. 1, Table 3), which amplified a $1.3-\mathrm{kb}$ fragment from the $5^{\prime}$ portion of the $R G C 2 B$ gene, revealed a polymorphism in the EMS mutant panel. The digestion products of mutant dm3e407 exhibited changes in intensity of several fragments (Fig. 2). When tested against the panel of BACs, these primers only amplified a fragment from the family member $R G C 2 B$; in addition, these primers did not amplify a product from any of the $d m 3$ deletion mutants (Meyers et al. 1998a). This provided further evidence that $R G C 2 B$ is the family member encoding $D m 3$ specificity.

Sequence analysis of EMS dm3 mutants. RGC2B was sequenced in each of the $d m 3$ mutants. The specificity of the primer, RLG2B5-1, to the $R G C 2 B$ homolog allowed the direct sequencing of the $5^{\prime}$ portion of the $R G C 2 B$ gene in each of the EMS mutants. A product of $4.2 \mathrm{~kb}$, which encompassed exons 1,2 , and 3, was amplified from mutant genomic DNA, using the primers RLG2B5-30 (an extension of RLG2B5-1) and 52Bintron2 in long PCR (Table 3). Direct sequencing of these PCR products detected one point mutation in each of the mutants dm3e310, dm3e407, dm3e1534, and dm3e1591 (Fig. 1, Table 4). Attempts to amplify larger fragments using RLG2B5-30, in order to sequence the entire gene, were unsuccessful. Sequences specific to the $3^{\prime}$ end of $R G C 2 B$ were unavailable. Therefore, primers were designed in intron 3 and in the $3^{\prime}$ untranslated region of $R G C 2 B$ that amplified $5.1-\mathrm{kb}$ products from a subset of $R G C 2$ homologs (Table 3). PCR products were amplified from genomic DNA of each mutant

Table 2. Ethylmethanesulphonate-induced $D m$ mutants in lettuce

\begin{tabular}{|c|c|c|c|c|c|}
\hline Mutant family $^{\mathbf{a}}$ & Specificity lost & $\mathbf{M}_{2}$ generation $\mathbf{R}: \mathbf{S}^{\mathbf{b}}$ & $\mathbf{P}\left(\chi_{(3: 1)}^{2}>x\right)$ for $M_{2}$ & $\mathrm{M}_{3}$ generation $\mathbf{R}: \mathrm{S}^{\mathrm{c}}$ & Molecular markers tested ${ }^{\mathrm{d}}$ \\
\hline dm1e390 & Dml & $27: 11$ & 0.57 & $0: 40$ & OPAB16, OPB19 \\
\hline dm1e753 & & $26: 9$ & 0.92 & $0: 62$ & OPAM11, OPV02 \\
\hline dm1e920 & & $52: 15$ & 0.62 & $0: 71$ & \\
\hline dm1e1727 & & $33: 12$ & 0.81 & $0: 55$ & \\
\hline $\mathrm{dm} 3 \mathrm{e} 310$ & $D m 3$ & $48: 14$ & 0.66 & $0: 62$ & OPAC15, OPAH17 \\
\hline dm3e407 & & $52: 16$ & 0.78 & $0: 50$ & OPAM14, OPE14, OPJ11 \\
\hline $\mathrm{dm} 3 \mathrm{e} 1368$ & & $26: 7$ & 0.69 & $0: 35$ & OPK13, OPM05, OPR14 \\
\hline dm3e1534 & & $40: 11$ & 0.66 & $0: 40$ & $\mathrm{OPX}_{11}, \mathrm{IPCR}_{800}, \mathrm{CL} 1795$ \\
\hline dm3e1591 & & $47: 10$ & 0.22 & $0: 71$ & MSAT15-34, MSATE6 \\
\hline $\mathrm{dm} 3 \mathrm{e} 1698$ & & $46: 8$ & 0.08 & $0: 47$ & RGC fingerprints \\
\hline $\mathrm{dm} 7 \mathrm{e} 46$ & $\operatorname{Dm} 7$ & $33: 10$ & 0.79 & $0: 62$ & OPA01, OPK02, OPH14 \\
\hline $\mathrm{dm} 7 \mathrm{e} 199$ & & $29: 8$ & 0.64 & $0: 80$ & \\
\hline dm7e211* & & $25: 9$ & 0.84 & $0: 60$ & \\
\hline dm7e449 & & $23: 7$ & 0.84 & $0: 30$ & \\
\hline dm7e1194* & & $27: 10$ & 0.78 & $0: 40$ & \\
\hline dm7e1437* & & $31: 12$ & 0.59 & $0: 58$ & \\
\hline dm8e101 & $D m 8$ & $30: 11$ & 0.60 & $0: 63$ & OPF12, OPD08, OPN13 \\
\hline $\mathrm{dm} 8 \mathrm{e} 275$ & & $27: 9$ & 0.82 & $0: 42$ & OPG06, OPX03, OPS12 \\
\hline dm8e 1730 & & $28: 10$ & 0.84 & $0: 56$ & OPU16 \\
\hline
\end{tabular}

\footnotetext{
a $*=$ Mutants with necrosis as well as profuse sporulation.

${ }^{\mathrm{b}} \mathrm{R}=$ number of resistant seedlings; $\mathrm{S}=$ number of susceptible seedlings.

${ }^{\mathrm{c}}$ Total $\mathrm{M}_{3}$ progeny from three susceptible $\mathrm{M}_{2}$ plants.

${ }^{\mathrm{d}}$ Molecular markers tested and determined to be present.
} 
and subcloned, and multiple clones were sequenced. One point mutation was detected in the $3^{\prime} R G C 2 B$ sequence for each of the mutants dm3e1368 and dm3e1698 (Fig. 1, Table 4). All point mutations conformed to the GC to AT transitions preferentially induced by EMS. The location of mutations did not appear to be clustered in any particular region of the gene. Two mutants, dm3e1534 and dm3e1591, had mutations at the same position; it is possible that, when these plants were harvested in the field, one plant was inadvertently treated as two separate plants due to a bifurcation of the apical meristem below the soil surface.

In four of the six dm3e mutants, the losses of Dm3 specificity were associated with three point mutations that resulted in nonconservative amino acid changes (Table 4). The G136E mutation in dm3e407 is in the N-terminal portion of the Dm3 protein which has no homologies to sequences in the databases. The remaining two mutations in $\mathrm{dm} 3 \mathrm{e} 310$, dm $3 \mathrm{e} 1534$, and dm3e1591 are at the beginning of the LRR-encoding region that constitutes approximately two-thirds of the protein. These two mutations (E603K and S610F, underlined) are in the sequence LSNLEVLSFANSHIEWLPSTVRN. This particular LRR is missing a residue relative to the $\mathbf{L x x L x x a x a x x}$ $(\mathrm{C} / \mathrm{L}) \mathbf{x} \mathbf{a x x a}$ consensus sequence that is characteristic of the LRRs in RGC2B; therefore, the site of the second mutation relative to the consensus is unclear. The nonconserved ' $x$ ' residues are hypothesized to be solvent exposed and potentially involved in the binding of pathogen-derived ligands (Jones and Jones, 1997; Kobe and Deisenhofer, 1994; Meyers et al. 1998b).

The point mutations in the remaining two dm3e mutants did not code for amino acid substitutions (Table 4). The mutation in $\mathrm{dm} 3 \mathrm{e} 1368$ introduced a premature ocher stop codon that would result in a deletion of the C-terminal third of the LRR from the protein product. In the mutant $\mathrm{dm} 3 \mathrm{e} 1698$, the mutation eliminated a donor splice site between the third intron and the fourth exon. The predicted $D m 3$ gene product in this mutant would be missing exon 4 that encodes approximately a third of the C-terminal LRR.

Isolation of $\mathrm{Dm} 3$ candidate sequences.

Previous transgenic complementation experiments with $R G C 2 B$-containing fragments derived from $\mathrm{BAC} \mathrm{H} 15$ failed to confer resistance due to the presence of a truncated copy of the $R G C 2 B$ gene in this BAC clone (Okubara et al. 1997). To obtain a full-length copy of $R G C 2 B$, a lambda library of genomic DNA from lettuce cv. Diana was constructed. Approximately 300,000 recombinant phage from an unamplified library were screened with the Dm3-associated markers AC15 (Anderson et al. 1996) and $I P C R_{800}$ (Okubara et al. 1997) and 134 positive clones were obtained. Ten of these positive clones contained the microsatellite marker MSAT15-34; this sequence is located within the largest intron of a subset of $R G C 2$ genes and distinguishes different family members (Meyers et al. 1998b). Four positives contained MSAT15-34:1, the array size that was characteristic of $R G C 2 B$ and missing in the $d m 3$ deletion mutants. The other six positives contained MSAT15-34 array sizes found in other $R G C 2$ family members and were not studied further.

To determine which clones contained the complete gene, the lambda clones were probed with different regions of $R G C 2$ genes and sequenced. Hybridization with probes corresponding to the region $5^{\prime}$ of $R G C 2 B$ resulted in banding patterns that were identical between two lambda clones $(\lambda 1$ and $\lambda 6)$ and BAC H15 (data not shown). The presence of the $3^{\prime}$ end in $\lambda 1$ and $\lambda 6$ was detected by hybridization with a probe corresponding to the $3^{\prime}$ untranslated region of a closely related family member $R G C 2 C$ (>80\% nt identity) (Meyers et al. 1998a). As expected, this $3^{\prime}$ probe did not hybridize to BAC H15. Hybridization of these probes to the other two $R G C 2 B$-containing lambda clones indicated that they did not contain a full-length

\section{A}

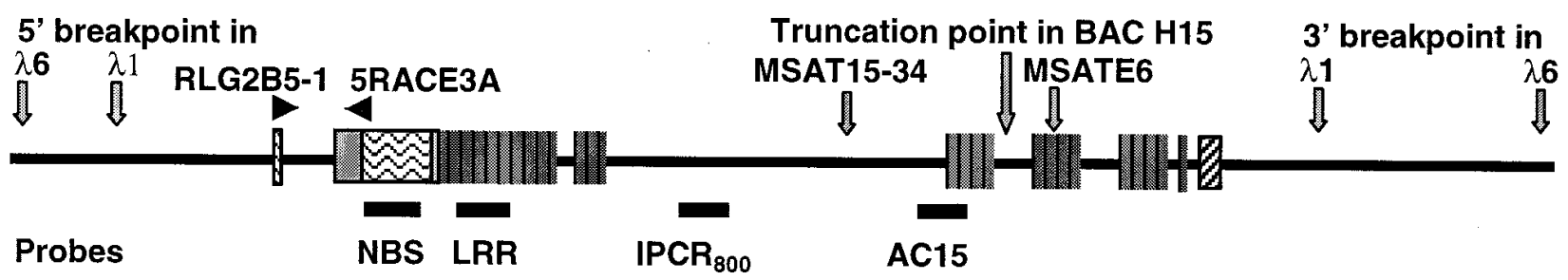

B

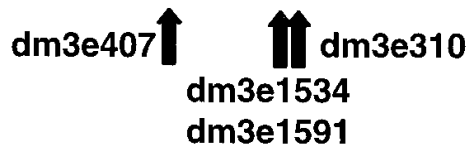

- 5'-untranslated sequence -120 bp
$=$ amino terminus
$=$ nucleotide binding site encoding region

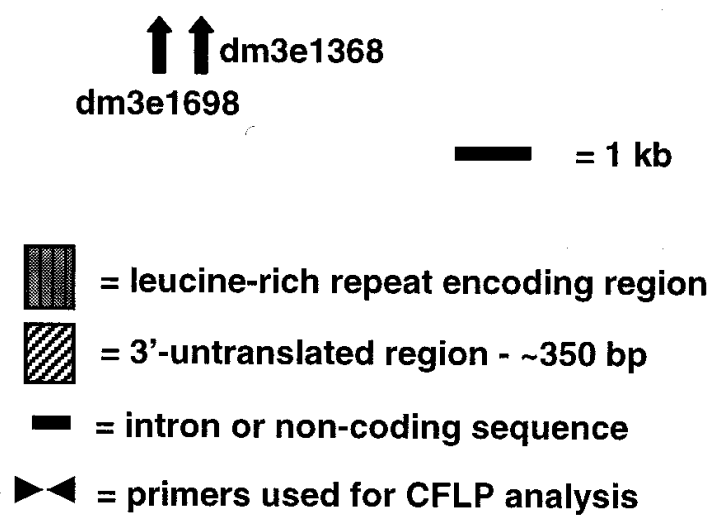

Fig. 1. Structure of $R G C 2 B$ gene used for transgenic complementation. A, Schematic of the $R G C 2 B$ gene in lambda clones, $\lambda 1$ and $\lambda 6$. Markers AC15, $\mathrm{IPCR}_{800}$ and MSAT15-34 were used to identify candidate $D m 3$ clones. $R G C 2 B$ from $\lambda 6$ was subcloned into the binary vector, pTiBAC for transgenic complementation experiments. Microsatellite MSATE6 was used for transcript analysis of the $R G C 2$ gene family. EMS-induced $d m 3$ mutants were screened with IPCR $_{800}$, MSAT15-34, and MSATE6. Locations of nucleotide binding site- and leucine-rich repeat-encoding probes used for RNA gel blot analysis are shown. B, Positions of point mutations in ethylmethanesulphonate-induced mutants of $\mathrm{Dm} 3$. 
copy of $R G C 2 B$ (data not shown) and were therefore not suitable candidates for transgenic complementation experiments. The $R G C 2 B$ gene was positioned within the clones by PCR using primers from the vector and terminal sequences of the open reading frame (ORF). The $\lambda 1$ and $\lambda 6$ clones contained inserts of 16 and $20 \mathrm{~kb}$ with approximately 3 plus $1.3 \mathrm{~kb}$ and 4.6 plus $4.4 \mathrm{~kb} 5^{\prime}$ and $3^{\prime}$ to the ORF, respectively. Nucleotide sequences from both $\lambda 1$ and $\lambda 6$ for the $5^{\prime}$ region of $R G C 2 B$ were identical to BAC H15. Therefore, $\lambda 1$ and $\lambda 6$ encompassed the entire $R G C 2 B$ gene (Fig. 1).

\section{Transgenic complementation of $\mathrm{Dm} 3$.}

Transgenics expressing $R G C 2 B$ were generated by Agrobacterium-mediated plant transformation and tested against several isolates of $B$. lactucae. The genomic fragment was subcloned from $\lambda 6$ into the low-copy binary vector pTiBAC and transformed into two genotypes lacking $D m 3$ specificity: Cobham Green, which contains no known functional $D m$ genes, and dm3e407, an EMS-induced $d m 3$ mutant of Diana. Leaf disks from all three primary transformants $\left(\mathrm{T}_{1}\right)$ of Cobham Green and three out of five independent primary transformants of $\mathrm{dm} 3 \mathrm{e} 407$ were resistant to Avr3-expressing isolate IM25P11 suggesting that $R G C 2 B$ conferred $D m 3$ specificity in transformed plants (data not shown). These transgenic plants were not resistant against isolate C96J504, which is virulent on both Cobham Green and wildtype Diana. Leaf disks from all dm3e407 transformants were resistant to isolate R60 due the action of $D m 7$ while leaf disks of Cobham Green were susceptible (data not shown). Together, these reactions indicate that the resistance conferred by the $R G C 2 B$ transgene is $D m 3$-specific.

Segregation of resistance to isolate IM25P11 was analyzed in $T_{2}$ progeny (Table 5). Segregation of resistant to susceptible $\mathrm{T}_{2}$ seedlings for the three independent Cobham Green transformants did not deviate significantly from a 3:1 ratio expected for a single integration event of a dominant transgene. One dm3e407 transformant produced no seeds. Of the remaining two dm3e407 $\mathrm{T}_{2}$ families, only one segregated for resistance close to a 3:1 ratio; the other was fully susceptible. Southern analysis of the $T_{1}$ progenitor of the susceptible $T_{2}$ family detected the presence of the transgene (data not shown); however, the resistant phenotype seemed to have been lost in the $\mathrm{T}_{2}$ generation. PCR amplification with primers for NptII confirmed that the resistance phenotype, when present, absolutely cosegregated with the T-DNA in 41 progeny from Cobham Green (28 resistant, 13 susceptible) and 45 progeny from $\mathrm{dm} 3 \mathrm{e} 407$ (31 resistant, 14 susceptible).

Specificity of $R G C 2 B$ to diverse isolates expressing Avr3.

To investigate the specificity of $R G C 2 B$ to $A v r 3$ further, the $\mathrm{T}_{2}$ transgenic progeny were tested against diverse $B$. lactucae isolates thought to be expressing Avr3 (Tables 1 and 5). Resistance to eight Avr3-expressing isolates from distinct geographical origins segregated in a 3:1 ratio in $T_{2}$ progeny of one Cobham Green transformant. Resistance to five of the eight isolates also segregated in $T_{2}$ progeny for one dm3e 407 transformant (three isolates were avirulent on $\mathrm{dm} 3 \mathrm{e} 407$ due to the presence of Avr genes in addition to Avr3). However, the segregation ratios for the $\mathrm{T}_{2}$ progeny of $\mathrm{dm} 3 \mathrm{e} 407$ were variable. Delayed sporulation occurred on up to $50 \%$ of the seedlings when inoculated with some isolates. This probably reflected partial penetrance of the transgene when hemizygous in this particular transformant. Similar patterns of sporulation are seen with some combinations of isolate and wildtype $\mathrm{Dm}$ gene (Maisonneuve et al. 1994), although wildtype Dm3 usually confers one of the clearer, more complete resistance reactions and partial penetrance is not observed in natural $D m 3 d m 3$ heterozygotes. The partial penetrance of hemizygotes in $\mathrm{dm} 3 \mathrm{e} 407$ was supported by $\mathrm{T}_{3}$ data. Homozygous $\mathrm{T}_{3}$ lines derived from dm3e407 were $100 \%$ resistant to all the isolates tested, while segregating families again showed an excess of susceptible individuals. $\mathrm{T}_{2}$ progeny of both Cobham Green and dm3e407 transgenics containing the empty pTiBAC vector were fully susceptible to all isolates tested. Therefore, $R G C 2 B$ conferred resistance to all isolates characterized as expressing Avr3 on the differential series of resistance cultivars and there was no

Table 3. Oligonucleotide primers used

\begin{tabular}{|c|c|c|c|}
\hline Primer & Sequence $\left(5^{\prime} \text { to } 3^{\prime}\right)^{a}$ & Position in $R G C 2 B$ & Purpose \\
\hline MSAT15-3 & GTATCACATCCСАААСТСТC & 5,848 & MSAT15-34 (Okubara et al., 1997) \\
\hline MSAT15-4 & GACAACAAAGTTGAACTGCC* & 5,733 & \\
\hline 3EXON4C & AGTGATTGTGAAGAAGGAAGAA & 10,083 & MSATE6 (Meyers et al., 1998a,b) \\
\hline 5MSATE6-1 & CCCAAGAAGAATCCTACCA & 10,265 & \\
\hline MSAT5E6 & AATGAAAGTGAT(A/T)GTGAAG & 10,077 & MSATE6 expression analysis \\
\hline MSAT3E6 & TC(A/T)TCCCCAAGAAGAA & 10,270 & \\
\hline 3RACE3A & GCCTTGTGTGGGATGGGTGGA & 529 & RGC fingerprint, CFLP analysis \\
\hline 5RACE3D & GCTCGTTTCAAAGACTTTGGGC & 1,173 & \\
\hline RLGF2 & GAGAAGCAAGAACCAGGCTCA & 1,313 & RGC fingerprint, CFLP analysis \\
\hline RLGR2 & GAACGCTCTGCCATCTCATTG & 2,015 & \\
\hline 3RACE3B & TCTGGGTTTATAGATGATAACTGC & 1,995 & RGC fingerprint, CFLP analysis \\
\hline $\mathrm{T} 7 / \mathrm{H} 15 / \mathrm{KSF} 2$ & GCACCGACACAATCCAAG & 3,046 & \\
\hline RLG2B5-1 & GATCAGAAGAGACTGTTCACAC & -755 & RGC fingerprint, CFLP analysis \\
\hline 5RACE3A & CACACAAGGCTACCATGTGGA & 538 & \\
\hline RLG2bB5-30 & GTAAGGAAGATCAGAAGAGACTGTTCACAC & -763 & Amplification for sequencing \\
\hline 5-2Bintron 2 & CCCAAGTTTAGTCATCCCACCTCTTTAT & 3,393 & \\
\hline 2Bintron2-3end & GACCAAGGTTTCTTCCAGGTACCATTTG & 7,648 & Amplification for sequencing \\
\hline 2B.3UTRA-B & CACCAGTCCACCGACTAGCTAACATCTA & 12,712 & \\
\hline 5RACE3F & GTGAACAGTCTCTTCTGATCTTCC & -736 & Analysis of $D m 3$ candidate clones \\
\hline 5RACE.EXONI & GATCTTCCTTACAAATACGAGAACTCG & -752 & $5^{\prime}$ transcript analysis \\
\hline 5RACEcDNA109 & CTGTCATTTTCATCTGCATGACCCTCAC & 136 & \\
\hline 5RACE3A-24 & CTAGTCTTCСССАСТССАСССАТС & 563 & \\
\hline 5RACE3D-26 & GGCAATAGGTAGACCGCAACACTTCC & 1,056 & \\
\hline 3RACEcDNAF4-28 & GTCACAAACAACTACCACTACTCTTGTC & 11,377 & $3^{\prime}$ transcript analysis \\
\hline 3RACEcDNAF5-28 & CGAATGCCCAGCAATAACCACCTTCACC & 11,812 & \\
\hline NptIIA & GAGGCTATTCGGCTATGACTG & & Amplification of T-DNA in transgenics \\
\hline NptIIB & ATCGGGAGCGGCGATACCGTA & & \\
\hline
\end{tabular}

$\mathrm{a} *=$ Correction from published sequence in Okubara et al. 1997. 
evidence for multiple resistance specificities encoded by wildtype $D m 3$ haplotypes.

\section{The $R G C 2$ transcript.}

The size of the $R G C 2$ transcript was estimated by RNA gel blot analysis. A single band of approximately $6.4 \mathrm{~kb}$ was detected in poly $(\mathrm{A})^{+}$RNA from Diana when probed with $R G C 2 B$ NBS- and LRR-encoding sequences (Fig. 3). This band is also present in Cobham Green, indicating at least some $R G C 2$ homologs are expressed in this cultivar that lacks any known functional resistance genes. The size of transcript is consistent with previous analysis of cDNA sequences that predict $R G C 2 B$ encodes an ORF of $5.43 \mathrm{~kb}$ (Meyers et al. 1998b).

The $5^{\prime}$ and $3^{\prime}$ ends of the $R G C 2 B$ transcript were identified using RACE PCR. The untranslated regions (UTRs) of $R G C 2 B$ were distinguished from those of other homologs on the basis of sequence identity within the ORF. $5^{\prime}$ RACE products containing $120 \mathrm{bp}$ of sequence upstream of the putative ATG of $R G C 2 B$ were obtained from multiple independent amplifications using nested primers. An in-frame stop codon was present $21 \mathrm{bp} 5^{\prime}$ to the putative ATG initiation codon. Comparison of $5^{\prime}$ RACE products to the genomic sequence revealed the presence of one intron of $703 \mathrm{bp}$ with consensus splice sites in the $5^{\prime}$ UTR. The presence of this intron was confirmed by amplification from genomic and cDNA. Sequences corresponding to the $3^{\prime}$ end of $R G C 2 B$ was obtained from RACE products terminating within 20 bp of each other approximately 350 bp downstream of the $R G C 2 B$ stop codon.

\section{$R G C 2$ expression.}

To determine the expression pattern of $D m 3$ and whether different members of the $R G C 2$ family were differentially regulated, we analyzed the expression of $R G C 2$ genes through-

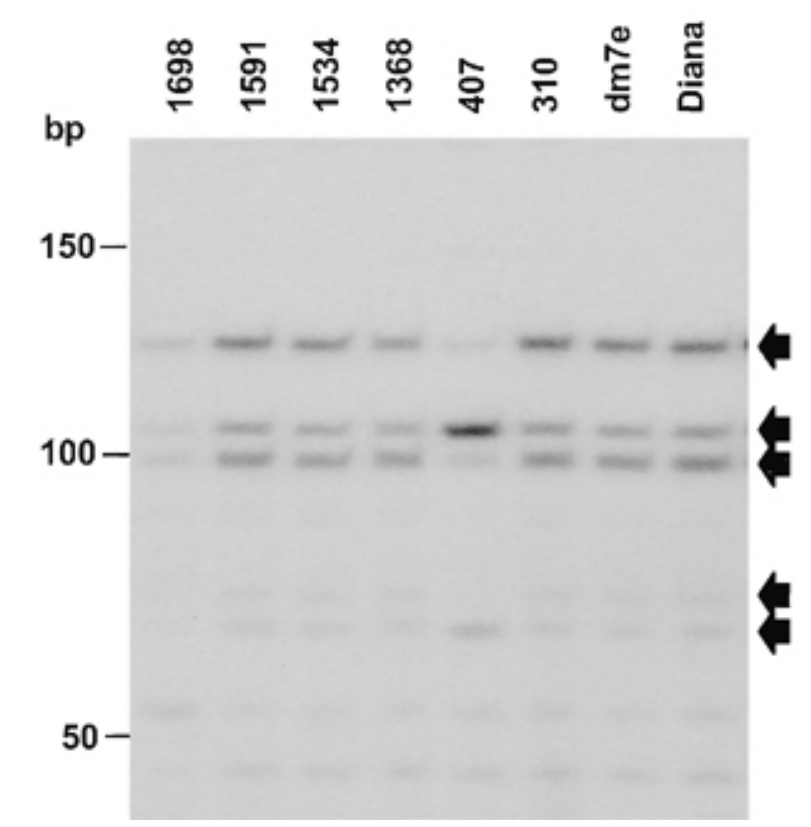

Fig. 2. Cleavase fragment length polymorphism analysis of ethylmethanesulphonate (EMS) $d m 3$ mutants. The primers RLG2B5-1 and 5RACE3A were used to amplify a 1.3-kb fragment from genomic DNA of the EMSinduced mutants of $D m 3$, a $d m 7$ mutant, and wildtype Diana. The oligonucleotide primer 5RACE3A was end-labeled with $\gamma-{ }^{32} \mathrm{P}$-ATP. The amplified fragment was denatured, partially digested with the endonuclease, Cleavase I (Invitrogen), and the products visualized on an 8\% (19:1) polyacrylamide gel. The mutant $\mathrm{dm} 3 \mathrm{e} 407$ exhibits a shift in intensity for several of the partially digested bands (arrows) due to a point mutation in the $D m 3$ sequence which resulted in a change in the double-stranded structures formed by the denatured polymerase chain reaction fragment. out the plant. At least 20 members of the $R G C 2$ family can be distinguished by the microsatellite marker MSATE6, a hypervariable trinucleotide repeat within exon 5 (Meyers et al. 1998a,b; H. Kuang and R. Michelmore, unpublished data). MSATE6 was amplified from cDNA of 3-, 5-, 6-, 8-, and 12day-old seedlings as well as from cDNA of buds, flowers, roots, and leaves of mature plants of cv. Diana (Fig. 4). At least $14 R G C 2$ genes are transcribed; six array sizes were absent from the cDNA products compared to the products from genomic DNA. The same pattern of array sizes was observed from all tissues; therefore, there was no evidence of differential expression of individual $R G C 2$ sequences relative to the tissues analyzed. There was amplification from all tissues indicating that all of the expressed $R G C 2$ genes are transcribed throughout development. However, this analysis is qualitative rather than quantitative; therefore, differences in the level of expression of all $R G C 2$ genes together would not have been detected.

\section{DISCUSSION}

$D m 3$ has been cloned by a combination of mutation analysis, map-based cloning, and candidate gene approaches. Different types of mutants were informative at different stages of the process. A member of the $R G C 2$ family, $R G C 2 B$, was identified as a candidate for $D m 3$ by analysis of deletion mutants for Dm3-linked markers. CFLP analyses of EMS-induced $d m 3$ mutants detected a polymorphism in the $R G C 2 B$ sequence of one mutant relative to wildtype Diana. Sequencing the entire $R G C 2 B$ gene from the EMS-induced $d m 3$ mutants revealed they all contained single base-pair substitutions that either formed a stop codon in the predicted ORF, effected an acceptor splice site, or resulted in nonconservative amino acid changes. These mutant analyses, however, did not rule out the possibility that additional mutations had occurred in a neighboring gene as well as in $R G C 2 B$. Transgenic complementation was necessary to prove that $R G C 2 B$ encoded $D m 3$ resistance.

Mutation experiments and transgenic assays provide complementary information in the cloning of resistance genes. Mutation experiments identify genes necessary for resistance; however, they may detect genes other than those determining specificity. Transgenic experiments can demonstrate sufficiency for the resistance phenotype; however, ectopic or overexpression of transgenes may result in a resistance phenotype that is not due to expression of the gene determining specificity, as in the case of transgenic expression of Prf in tomato (Salmeron et al. 1996). It is therefore necessary to demonstrate race specificity of the mutants and the transgene. All six dm3e mutants were tested against a panel of five B. lactucae isolates from diverse geographical origins, each containing the Avr3 gene and therefore avirulent on wildtype cv. Diana. All six mutants were fully susceptible to all five isolates. Thus, the point mutations were specific to the Dm3-Avr3 interaction and there was no evidence for multiple specificities encoded by the $D m 3$ locus. Transgenic plants expressing $R G C 2 B$ were fully resistant to this same panel of five isolates. Together, the analyses of the EMS mutants and the transgenic plants demonstrated that the $R G C 2 B$ sequence was both necessary and sufficient to provide $D m 3$-encoded resistance.

The Dm3 gene is approximately $14.5 \mathrm{~kb}$ long with seven introns and a 5.9-kb transcript. A 703-bp intron in the $5^{\prime}$ UTR places the promoter at least $731 \mathrm{bp}$ upstream of the initiation codon. Northern analysis detected only a single band suggesting homogeneous transcript size from the $R G C 2$ homologs and provided no evidence of alternative splicing. Dm 3 shares 70 to $98 \%$ amino acid identity to other deduced RGC2 proteins. 
There is a short 181 amino acid region N-terminal to a NBS domain. The NBS domain has motifs characteristic of non-TIR NBS-LRR encoding resistance genes from other species (Meyers et al. 1999). There are no obvious transmembrane or kinase domains. It has an unusually large LRR-encoding region that is approximately twice the size of LRR-encoding regions of resistance genes from other plants. The approximately 40 LRRs are somewhat irregular but contain the consensus $\operatorname{LxxLxxaxaxx}(\mathrm{N} / \mathrm{C} / \mathrm{T}) \mathrm{xxaxxa}$ motif found in other resistance genes, in which the ' $x$ ' residues are proposed to be solvent exposed (Jones and Jones 1997) and show evidence of divergent selection (Meyers et al. 1998b; Parniske et al. 1997). The two mutants with deletions in the C-terminal LRR demonstrate that this region is required for $D m 3$ activity and is consistent with the spontaneous loss of $\mathrm{Dm} 3$ activity due to a gene conversion event in this region (Chin et al. 2001).

Overexpression of the resistance genes Pto, Rps2, and Prf can lead to constitutive activation of defense responses in the absence of cognate avirulence gene expression (Oldroyd and Staskawicz 1998; Tang et al. 1999; Tao et al. 2000). To decrease the likelihood that overexpression would mask specificity of the resistance response, $R G C 2 B$ was introduced under the control of the native promoter. Plants carrying the $R G C 2 B$ transgene were not resistant to isolates not expressing Avr3, confirming that the resistance phenotype was specific to $\mathrm{Dm} 3$ and not due to overexpression of the transgene.

There is little data on the expression of $R$ genes. Most $R$ genes appear to be expressed constitutively at low levels (e.g., RPP5 from Arabidopsis [Parker et al. 1997] and $L 6$ from flax [Ayliffe et al. 1999]). RNA blot analysis indicated that $R G C 2$ homologs are expressed in both susceptible and resistant lines. The transcript was not detected when total RNA was probed and the use of poly $(\mathrm{A})^{+}$RNA produced weak hybridization signals, indicating that, although expression was constitutive, the message was present in low abundance. Thus far, there have been only two reports of induced $R$ gene expression. The $P i b$ rice resistance gene is expressed constitutively at low levels but shows increased expression following inoculation with both incompatible and compatible pathogen races, although similar induction was observed under mock inoculation conditions (Wang et al. 1999). Xal gene expression is detected from resistant rice lines only upon induction by pathogen infection or wounding (Yoshimura et al. 1998). The induction of $R G C 2$ expression in response to pathogen challenge was not investigated because infection by $B$. lactucae results in asynchronous colonization of the host tissue and, even when the pathogen sporulates, only a minority of cells are in contact with the pathogen. Reverse transcriptase (RT)-PCR analysis of MSATE6 revealed that, in wildtype cv. Diana, Dm3 and many of the other $R G C 2$ family members are expressed; however, whether other $R G C 2$ paralogs encode resistance to other isolates of $B$. lactucae or other pathogens remains to be determined. Inoculation with multiple isolates of B. lactucae provided no evidence for additional specificities encoded by other $R G C 2$ paralogs in the $D m 3$ haplotype.

Lettuce seedlings of resistant genotypes sometimes support growth of avirulent isolates when inoculated at very early stages (unpublished observations). However, no clear differences in global or specific expression of $R G C 2$ members were observed at different developmental stages. Similar results have been observed with other $R$ genes. RT-PCR demonstrated that $L 6$ is expressed in various organs, including roots that are not attacked by flax rust; in addition, $L 6$ does not appear to be induced upon pathogen challenge (Ayliffe et al. 1999). Xa21 expression also appears to be independent of developmental stage, pathogen challenge, and wounding; however, the resistance phenotype increases with age and, therefore, expression of Xa21 could not be correlated with expression of Xa21-mediated disease resistance (Century et al. 1999). In contrast, $r p l$ transcript levels in maize varied during leaf development; there was no clear evidence that expression of genes at the rpl complex was induced upon inoculation with either virulent or avirulent pathogen races of rust (Collins et al. 1999). These results indicate that factors other than the transcription of the $R$ gene influence the level of resistance observed.

EMS mutants also were identified for the other three $D m$ loci $(D m 1, D m 7$, and $D m 8)$ present in wildtype Diana. Each mutant displayed a complete loss of resistance for only one of the four specificities. All mutations were recessive and stable; allelism tests showed no evidence for intergenic complementation. Therefore, lesions in all EMS mutants occurred at the same $D m$ locus within each specificity group and no additional loci involved in the disease response were identified. A previous study of FN-induced mutants in lettuce also had failed to reveal mutable loci other than the resistance genes (Okubara et al. 1994). Candidate sequences have yet to be identified for $D m 1, D m 7$, and $D m 8$. When they are, these mutant stocks will undoubtedly be critical in the cloning of these resistance specificities.

This lack of intergenic complementation displayed in the mutants may result from redundancy in components of the signal transduction pathway or from the requirement of these components for viability. Additionally, some pathways may be branched such that lesions in one branch produce only partial losses in resistance (Innes 1998). However, signal transduction pathways involved in disease resistance are being successfully dissected by mutant analyses for a variety of plants (Glazebrook 1999; Innes 1998; Schulze-Lefert et al. 1997). Mutation studies have identified the Rarl and Rar2 genes in barley (Freialdenhoven et al. 1994; Peterhansel et al. 1997); Rcrl and Rcr2 (Hammond-Kosack et al. 1994), Rcr3 (Dixon et al. 2000), and $\operatorname{Prf}$ (Salmeron et al. 1994) in tomato; as well as many genes in Arabidopsis, including NDR1, EDS1, NIM1, NPR1, PAD1-PAD4, and PBS1-PBS3 (Cao et al. 1994; Century et al. 1995, 1997; Delaney et al. 1995; Falk et al. 1999; Glazebrook et al. 1997; Parker et al. 1996; Warren et al. 1999) in addition to the primary $R$ genes. It is possible that there is greater redundancy in lettuce, or our focus on only complete losses of resistance resulted in the lack of identification of complementary loci.

Over 70 lettuce EMS mutants were identified that exhibited partial losses of resistance with varying levels of necrosis and sporulation. The high frequency of necrotic phenotypes suggested that lesions in many loci could result in this phenotype. Some of these families may contain mutations in components of the signal transduction pathway. Detailed analyses of these mutants will require multifactorial genetic tests to identify complementation groups, as well as more quantitative assays for resistance.

Classical and molecular genetic analyses have now shown that there are at least 10 resistance specificities encoded in the Dml/3 region distributed over multiple genotypes (Farrara et

Table 4. Point mutations in ethylmethanesulphonate-induced $d m 3$ mutants

\begin{tabular}{|c|c|c|}
\hline $\begin{array}{l}\text { Mutant } \\
\text { family }\end{array}$ & 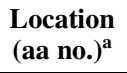 & Type of mutation \\
\hline 310 & 610 & serine $(\mathrm{TCT})>$ phenylalanine $(\mathrm{TTT})$ \\
\hline 407 & 136 & glycine (GGA) > glutamic acid (GAA) \\
\hline 1368 & 1,280 & glutamine $(\mathrm{CAA})>$ STOP $($ TAA $)$ \\
\hline 1534 & 603 & glutamic acid (GAA) > lysine (AAA) \\
\hline 1591 & 603 & glutamic acid (GAA) > lysine (AAA) \\
\hline 1698 & 1,058 & $\begin{array}{l}\text { RNA splice site } \\
\text { (GATTGAAATTC }>\text { AATTGAAATTC) }\end{array}$ \\
\hline
\end{tabular}

\footnotetext{
${ }^{\mathrm{a}}$ Location of mutation (amino acid number).
} 
al. 1987); some but not all of these specificities map precisely to the Dm3 locus and therefore may be $R G C 2$ homologs. The cloning and characterization of $D m 3$ provides the opportunity to characterize the specificities encoded by $R G C 2$ homologs in other genotypes. Approximately 15 to $35 R G C 2$ paralogs are present in different haplotypes (Meyers et al. 1998a; H. Kuang and R. Michelmore, unpublished data). The challenge is to develop efficient cloning procedures that allow the dissection and analysis of such complex multigene families.

\section{MATERIALS AND METHODS}

\section{Plant material and mutagenesis.}

Seed of the lettuce butterhead cv. Diana (Dm1, Dm3, Dm7, and $D m 8)$ were agitated in aerated solutions of 0.5 or $0.05 \%$ (vol/vol) EMS (Sigma-Aldrich, St. Louis), with $0.025 \%$ (vol/vol) Tween 20 detergent (Fisher Scientific, Pittsburgh, PA) for $12 \mathrm{~h}$, washed once in distilled water for approximately $30 \mathrm{~min}$, and then rinsed in distilled water four times. $\mathbf{M}_{1}$ seeds were planted and grown to maturity in the greenhouse, generating over 3,000 $\mathrm{M}_{2}$ families. The higher dosage of $0.5 \%$ (vol/vol) EMS resulted in weak plants that did not produce abundant seed.

\section{Assays for loss of downy mildew resistance.}

Isolates of B. lactucae were propagated on 7-day-old seedlings of the lettuce cv. Cobham Green, which contains no known functional $D m$ genes; asexual spores were harvested 7 days after inoculation, as described previously (Farrara and Michelmore 1987). Primary screens were conducted by inoculating 6- to 7-day-old $\mathrm{M}_{2}$ seedlings with a mixture of four isolates of B. lactucae, each diagnostic for one of the four $\mathrm{Dm}$ genes in Diana (Table 1). For mutant screens, 20 to 25 lettuce seedlings of each $\mathrm{M}_{2}$ family were tested. Wildtype resistant seedlings showed no macroscopic reaction to inoculation and supported no sporulation of B. lactucae. Conversely, loss of resistance resulted in profuse asexual sporulation 6 to 10 days postinoculation, with or without host necrosis. All susceptible seedlings were given multiple treatments of the systemic fungicide Ridomil 2E (Ciba-Geigy Corp., Greensboro, NC) before being transferred to soil. Efficiency of rescue for each mutant family was $100 \%$. To determine which $\mathrm{Dm}$ gene was inactivated in each putative mutant family, secondary screens were conducted on additional $\mathrm{M}_{2}$ seedlings using each of the isolates of B. lactucae individually.

\section{Genetic analyses of EMS mutants.}

Mutant $\mathrm{M}_{2}$ families were scored for the segregation of resistance. The mutant phenotype was confirmed by inoculation of 25 to $40 \mathrm{M}_{3}$ seed from three susceptible individuals of each $\mathrm{M}_{2}$ family, with the appropriate isolate of B. lactucae.
To determine the number of loci affected, complementation tests were conducted by intercrossing mutants exhibiting loss of the same $D m$ activity. In addition, the EMS-induced mutants were crossed to the previously isolated FN-induced mutants (Okubara et al. 1994) as well as wildtype Cobham Green and Diana. In most cases, reciprocal crosses were made. Selfed individuals could not be distinguished from outcrossed $F_{1}$ individuals in all tests; however, crosses between mutants and Cobham Green or wildtype Diana, in which the $F_{1}$ genotype could be determined by screening with isolates that detected other $D m$ genes, indicated that the average crossing rate was $55 \%$.

\section{Molecular analyses of EMS mutants.}

DNA was isolated from lettuce leaves using a modified cetyltrimethylammonium bromide procedure (CTAB; Bernatzky and Tanksley 1986). Mutants were analyzed for markers known to map to the clusters of $D m$ genes as described previously (Kesseli et al. 1993; Okubara et al. 1994; Paran et al. 1991; Sicard et al. 1999).

Fragments of $R G C 2$ genes were amplified by PCR using oligonucleotide primers in the NBS- and LRR-encoding regions designed from sequences described previously (Meyers et al. 1998b; Shen et al. 1998). Fingerprints of $R G C$ sequences were obtained by digestion of the amplification products with one of several four base restriction endonuclease enzymes (including Tsp509I; New England Biolabs, Beverly, MA), followed by electrophoresis in $8 \%(19: 1)$ polyacrylamide gels and staining with SYBR Green (FMC BioProducts, Rockland, ME).

The amplified $R G C$ fragments also were analyzed using the CFLP kit (Invitrogen, Carlsbad, CA, U.S.A.). Amplified products from EMS-induced mutants were end-labeled with $\gamma-{ }^{32} \mathrm{P}$, denatured, incubated with Cleavase I at 45 to $55^{\circ} \mathrm{C}$, and visualized on 8\% (19:1) polyacrylamide gels.

For the sequencing of EMS mutants, large fragments were amplified from genomic DNA using PCR with the polymerases Pfu (Stratagene, La Jolla, CA) or BIO-X-ACT (Intermountain Scientific Corp., Kaysville, UT), which have $3^{\prime}$ to $5^{\prime}$ proofreading activity, using two-step PCR: initial denaturation at $94^{\circ} \mathrm{C}$ for $2 \mathrm{~min}$, followed by 15 to 25 cycles of $20 \mathrm{~s}$ at $92^{\circ} \mathrm{C}$ and 9 to $11 \mathrm{~min}$ at $68^{\circ} \mathrm{C}$, with a final extension of $72^{\circ} \mathrm{C}$ for 6 or $9 \mathrm{~min}$ and a $10^{\circ} \mathrm{C}$ hold. Amplification products were sequenced directly after gel purification using NA45 DEAE cellulose membrane (Schleicher \& Schull, Keene, NH) or after subcloning using the TOPO-XL kit (Invitrogen). All sequencing was performed with a dye terminator cycle sequencing kit and an ABI 377 automated sequencer (Applied Biosystems Inc., Foster City, CA). Nucleotide sequences were analyzed using the software package Sequencher (Genecodes, Ann Arbor, MI). The deduced protein sequences were analyzed with the software program Peptool 1.0 (Biotools Inc., Edmonton, AB, Canada).

Table 5. Segregation data for $R G C 2 B$ transgenic plants

\begin{tabular}{|c|c|c|c|c|c|c|c|}
\hline \multirow[b]{2}{*}{ Isolate } & \multicolumn{2}{|c|}{ Cobham Green $+R G C 2 B$} & \multicolumn{5}{|c|}{$\operatorname{dm} 3 \mathrm{e} 407+R G C 2 B$} \\
\hline & $\begin{array}{c}\mathbf{T}_{2} \text { generation } \\
\text { R:S } \\
\end{array}$ & $\begin{array}{c}\mathbf{P}\left(\chi_{(3: 1)}^{2}\right) \text { for } \\
\mathbf{T}_{2}\end{array}$ & $\mathbf{T}_{2}$ generation $\mathbf{R}: \mathrm{S}$ & $\begin{array}{c}\mathbf{P}\left(\chi_{(3: 1)}^{2}\right) \\
\text { for } \mathbf{T}_{2}\end{array}$ & $\begin{array}{c}\mathbf{T}_{3} \text { generation } \\
\mathbf{R}: \mathbf{S}^{\mathbf{b}} \\
\end{array}$ & $\begin{array}{c}\mathbf{P}\left(\chi^{2}{ }_{(3: 1)}\right) \\
\text { for } \mathbf{T}_{3}\end{array}$ & $\begin{array}{c}\mathbf{T}_{3} \text { generation } \\
\mathbf{R}: \mathbf{S}^{\mathbf{c}}\end{array}$ \\
\hline IM25P11 & $144: 54$ & 0.46 & $130: 29$ & 0.050 & $58: 22$ & 0.60 & $40: 0$ \\
\hline $\mathrm{AM}$ & $59: 21$ & 0.80 & $20: 58$ & $<0$ & $40: 40$ & $<0$ & $40: 0$ \\
\hline IL4 & $58: 20$ & 0.90 & 29:11 & 0.72 & $53: 27$ & 0.07 & $40: 0$ \\
\hline C99S744 & $60: 19$ & 0.84 & $41: 39$ & $<0$ & $48: 32$ & $<0$ & $40: 0$ \\
\hline CG5 & $61: 19$ & 0.80 & $18: 61$ & $<0$ & $61: 19$ & 0.80 & $40: 0$ \\
\hline SF5 & $60: 20$ & 1.00 & Avirulent due to $A v r l$ & & & & \\
\hline NL6 & $53: 19$ & 0.78 & Avirulent due to $A v r 7$ & & & & \\
\hline CS12 & $56: 24$ & 0.30 & Avirulent due to $A v r l$ & & & & \\
\hline
\end{tabular}

${ }^{\mathrm{a}} \mathrm{R}=$ number of resistant seedlings; $\mathrm{S}=$ number of susceptible seedlings.

${ }^{\mathrm{b}} \mathrm{dm} 3 \mathrm{e} 407 \mathrm{~T}_{3}$ progeny heterozygous for $R G C 2 B$ transgene.

${ }^{c} \mathrm{dm}_{3} \mathrm{e} 407 \mathrm{~T}_{3}$ progeny homozygous for $R G C 2 B$ transgene. 


\section{Library construction and screening.}

Genomic DNA isolated from cv. Diana (Dm1, Dm3, Dm7, and $D m 8$ ) was partially digested with Sau3AI and size fractionated by sucrose gradient centrifugation. DNA from fractions containing fragments of 15 to $25 \mathrm{~kb}$ were precipitated and inserted into the BamHI site of the Lambda DASH II vector (Stratagene, La Jolla, CA). Ligated DNA was packaged into phage using Gigapack II XL (Stratagene) and transfected into XL1-Blue MRA (P2) host cells (Stratagene). Library screens and hybridizations were performed essentially as described by Sambrook and associates (1989). Microsatellite marker MSAT15-34 was amplified from primary plugs using PCR conditions described previously (Okubara et al. 1997). Recombinant bacteriophage carrying $R G C 2 B$ were purified using the Qiagen Lambda Maxi Kit (Qiagen, Valencia, CA). $\mathrm{T} 3$ and $\mathrm{T} 7$ primers were used in conjunction with $R G C 2 B$-specific primers 5RACE3F and 3RACEcDNAF5-28 to estimate the size of the inserts and position the ORF within the clones.

\section{Lettuce transformation.}

$R G C 2 B$ was released from the Lambda DASH II vector by digestion with NotI and cloned into the binary vector pTiBAC (S. Kim and R. Michelmore, unpublished data). This is a low copy vector in both Escherichia coli and Agrobacterium spp. due to the use of F1 and Ri oris. Either the empty pTiBAC vector or pTiBAC containing $R G C 2 B$ was electroporated into Agrobacterium tumefaciens strain LBA4404 and introduced into lettuce cv. Cobham Green and the $d m 3$ EMS-induced mutant of cv. Diana dm3e407 (Okubara et al. 1997) by Agrobacterium-mediated transformation using cocultivation procedures described previously (Michelmore et al. 1987). Transformants were selected on regeneration media containing $50 \mathrm{mg}$ of kanamycin per liter followed by rooting media containing 25

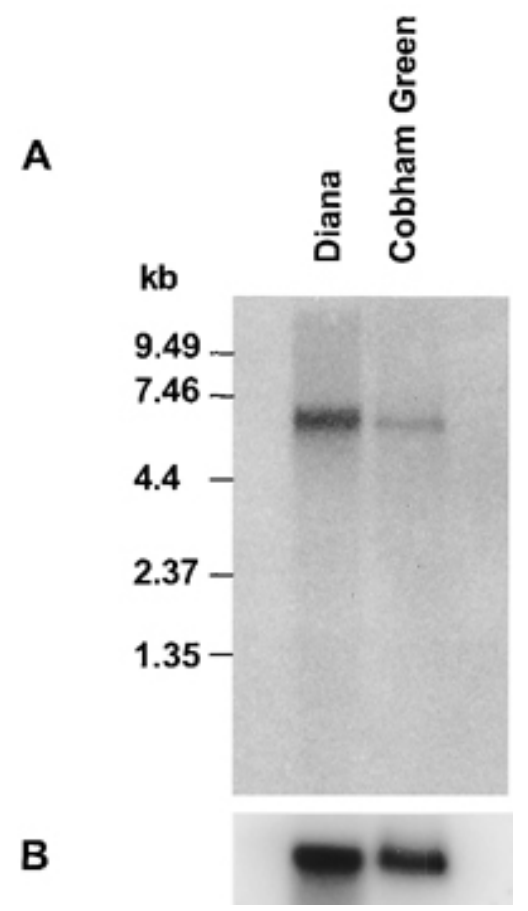

Fig. 3. RNA gel blot analysis with $R G C 2 B$. A, Approximately $5 \mu \mathrm{g}$ of poly $(\mathrm{A})^{+}$RNA from lettuce cvs. Diana $(D m 1, D m 3, D m 7$, and $D m 8)$ and Cobham Green (no known $D m$ genes) were hybridized with probes corresponding to $1,300 \mathrm{bp}$ encoding the nucleotide binding site and a portion of the leucine-rich repeat from $R G C 2 B$. A single band of approximately 6.4 $\mathrm{kb}$ was obtained from both genotypes. B, The blot was rehybridized with a lettuce Ribulose-1,5-bisphosphate carboxylase/oxygenase (RubisCO) probe as a control for RNA loading. This indicated there was slightly less RNA from Cobham Green. $\mathrm{mg}$ of kanamycin per liter before being grown to maturity in the greenhouse.

\section{Analyses of transgenic plants.}

Leaf disks from primary lettuce transformants $\left(\mathrm{T}_{1}\right.$ generation) were inoculated with Bremia lactucae isolate IM25P11, which is avirulent on lettuce genotypes expressing Dm3. Resistance or susceptibility to IM25P11 was assayed by the absence or presence of asexual sporulation 8 to 15 days postinoculation. Similarly, segregation of resistance in the $T_{2}$ and $\mathrm{T}_{3}$ generations was determined by inoculating 6- to 8-dayold lettuce seedlings with a collection of B. lactucae isolates avirulent on Dm3 (Tables 1 and 5). In all, 40 to 80 seedlings for each $\mathrm{T}_{2}$ and $\mathrm{T}_{3}$ population were scored for segregation of resistance. Genomic DNA was extracted from individuals resistant and susceptible against isolate IM25P11 and cosegregation of the resistance phenotype with the T-DNA was confirmed by PCR amplification of NptII using primers NptIIA
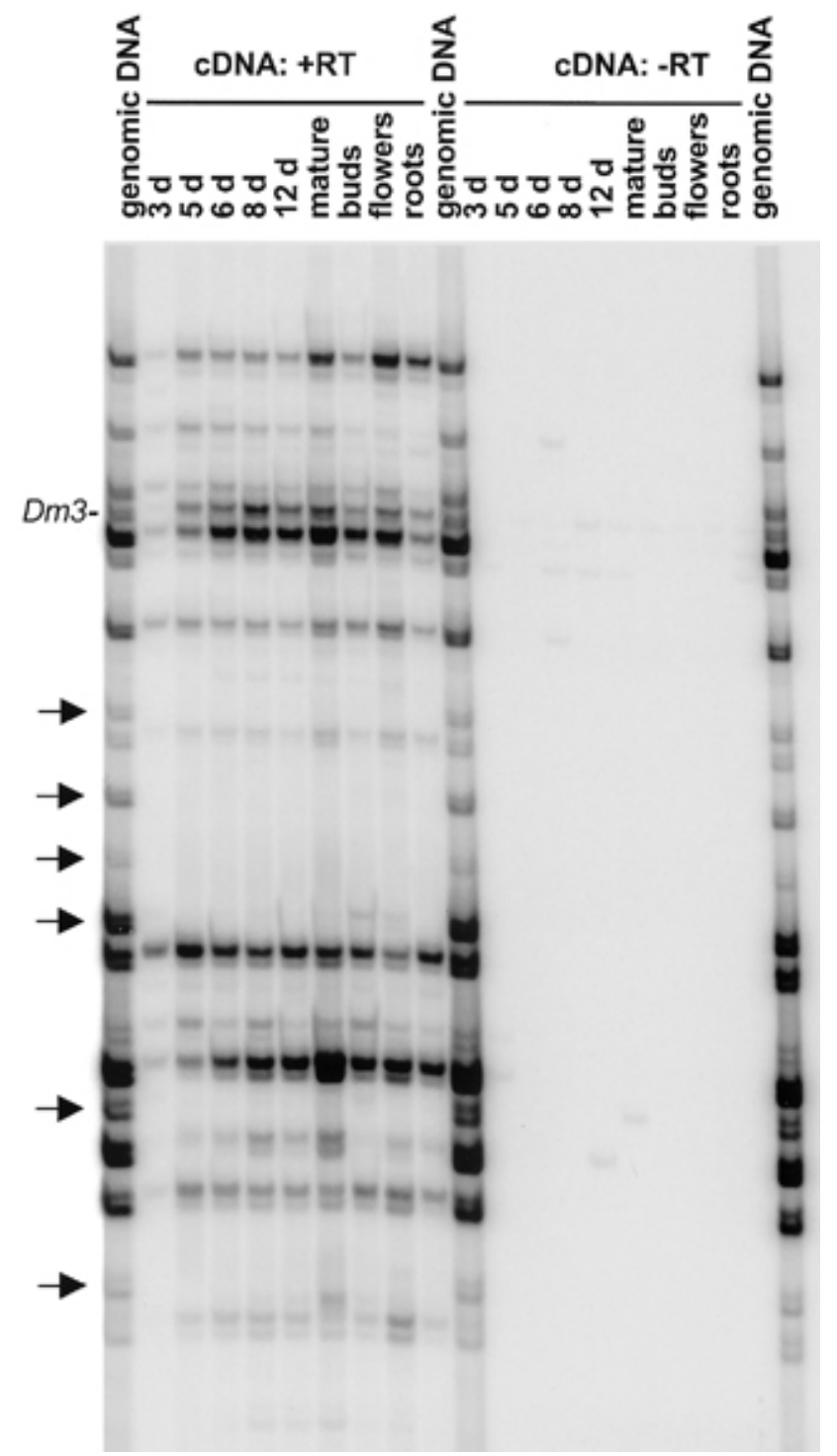

Fig. 4. Analysis of $R G C 2$ gene expression in Diana. Reverse transcriptase-polymerase chain reaction (RT-PCR) amplification of MSATE6, an in-frame trinucleotide repeat in exon 5 that distinguishes different $R G C 2$ members, was used to assay expression of $R G C 2$ genes in cv. Diana. $+\mathrm{RT}$ $=$ amplification from cDNA of seedlings $(3,5,6,8$, and 12 days post sowing), buds, flowers, roots, and mature leaves. $-\mathrm{RT}=$ reactions performed in the absence of reverse transcriptase. Arrows indicate arrays not detectable by RT-PCR in cDNA compared to genomic DNA. 
and NptIIB. B. lactucae isolates R60 (avirulent on lettuce genotypes such as Diana that express $D m 7$ ) and C96J504 (virulent on cvs. Diana and Cobham Green) were used as controls to test the specificity of the $R G C 2 B$ transgene.

\section{RT-PCR and transcript analysis.}

Total RNA was extracted from Diana seedlings (3, 5, 6, 8, and 12 days post sowing), buds, flowers, mature leaves, and roots using the Qiagen RNeasy Plant Miniprep kit (Qiagen). The RNA was subsequently subjected to DNase treatment (Roche Molecular Biochemicals, Indianapolis, IN). Firststrand cDNA was synthesized from total RNA using an Oligo(dT) 16-mer using SuperScript II reverse transcriptase (Life Technologies, Gibco BRL, Rockville, MD) according to the manufacturer's instructions. First-strand cDNA synthesis reactions lacking SuperScript II reverse transcriptase were carried out simultaneously as controls to check for possible amplification from contaminating genomic DNA.

Microsatellite MSATE6 was amplified using primers MSAT5E6 and MSAT3E6. The MSAT5E6 primer was end labeled with $\gamma-{ }^{32} \mathrm{P}$ ATP (NEN, Boston, MA). PCR reactions were carried out for 30 cycles of $30 \mathrm{~s}$ at $94^{\circ} \mathrm{C}, 30 \mathrm{~s}$ at $50^{\circ} \mathrm{C}, 30 \mathrm{~s}$ at $72^{\circ} \mathrm{C}$, and resolved on a $6 \%$ denaturing polyacrylamide gel.

For Northern analysis, total RNA was extracted using TRI REAGENT (Sigma-Aldrich) as specified by the manufacturer. Poly $(\mathrm{A})^{+}$RNA was purified from total RNA of Diana and Cobham Green using oligo(dT)-cellulose columns (Amersham Pharmacia Biotech, Piscataway, NJ). Approximately $5 \mu \mathrm{g}$ of poly $(\mathrm{A})^{+}$RNA per lane was separated on a formaldehyde denaturing gel, transferred to positively charged nylon membrane (NEN), and hybridized with two probes corresponding to $1,300 \mathrm{bp}$ encoding the NBS and a portion of the LRR of $R G C 2 B$ (Fig. 1). Labeling, hybridization, and wash procedures were performed according to standard protocols (Sambrook et al. 1989). The blot was subjected to a final wash of $30 \mathrm{~min}$ at $65^{\circ} \mathrm{C}$ in $0.2 \times \mathrm{SSC}(1 \times \mathrm{SSC}$ is $0.15 \mathrm{M} \mathrm{NaCl}$ and $0.015 \mathrm{M}$ sodium citrate) $/ 0.1 \%$ sodium dodecyl sulfate. Bands were sized using the 0.24- to 9.5-kb RNA ladder (Invitrogen).

To identify the $5^{\prime}$ and $3^{\prime}$ ends of the $R G C 2 B$ transcript, template cDNA for RACE PCR reactions was generated from Diana poly $(\mathrm{A})^{+}$RNA using the Clontech SMART cDNA library synthesis kit (Clontech, Palo Alto, CA). Gene-specific primers 5RACE.EXONI, 5RACEcDNA109, 5RACE3A-24, and 5RACE3D-26 were used in combination with the commercial $5^{\prime}$ PCR primer to generate nested PCR products for the $5^{\prime}$ end of the transcript (Fig. 1). For the $3^{\prime}$ end of the transcript, 3RACEcDNAF4-28 and 3RACEcDNAF5-28 gene-specific primers were used in combination with the commercial CDSIII/3' PCR primer. Touchdown PCR conditions used for the RACE reactions included 5 cycles of $5 \mathrm{~s}$ at $94^{\circ} \mathrm{C}, 3 \mathrm{~min}$ at $72^{\circ} \mathrm{C} ; 5$ cycles of $5 \mathrm{~s}$ at $94^{\circ} \mathrm{C}, 3 \mathrm{~min}$ at $70^{\circ} \mathrm{C}$; and 20 cycles of $5 \mathrm{~s}$ at $94^{\circ} \mathrm{C}, 3 \mathrm{~min}$ at $68^{\circ} \mathrm{C}$. PCR bands were gel purified using the QIAEX II gel extraction kit (Qiagen) and cloned into pCR$\mathrm{XL}$ (Invitrogen). Clones containing $R G C 2$ sequences were identified by colony hybridization using probes corresponding to the $5^{\prime}$ and $3^{\prime}$ ends of $R G C 2 B$. Positive clones were sequenced at the University of California-Davis Plant Genetics Facility and evaluated using Sequencher (Genecodes) and Phred/Phrap/Consed (University of Washington Genome Center, Seattle) software.

\section{ACKNOWLEDGMENTS}

We thank Harpreet Johl and Grace Salcedo for their help in conducting the phenotypic screens that identified mutant families displaying losses of Dm resistance. This work was supported by U.S. Department of Agriculture National Research Initiative Competitive Grant Program (Grant \#9835300-6188 and \#95-37300-1571).

\section{LITERATURE CITED}

Aarts, M. G., te Lintel Hekkert, B., Holub, E. B., Beynon, J. L., Stiekema, W. J., and Pereira, A. 1998. Identification of R-gene homologous DNA fragments genetically linked to disease resistance loci in Arabidopsis thaliana. Mol. Plant-Microbe Interact. 11:251-258.

Anderson, P. A., Okubara, P. A., Arroyo-Garcia, R., Meyers, B. C., and Michelmore, R. W. 1996. Molecular analysis of irradiation-induced and spontaneous deletion mutants at a disease resistance locus in Lactuca sativa. Mol. Gen. Genet. 251:316-325.

Ayliffe, M. A., Frost, D. V., Finnegan, E. J., Lawrence, G. J., Anderson, P. A., and Ellis, J. G. 1999. Analysis of alternative transcripts of the flax L6 rust resistance gene. Plant J. 17:287-292.

Baker, B., Zambryski, P., Staskawicz, B., and Dinesh-Kumar, S. P. 1997. Signaling in plant-microbe interactions. Science 276:726-733.

Bernatzky, R., and Tanksley, S. D. 1986. Genetics of actin-related sequences in tomato. Theor. Appl. Genet. 72:314-321.

Bonnier, F. J. M., Reinink, K., and Groenwald, R. 1994. Genetic analysis of Lactuca accessions with new major gene resistance to lettuce downy mildew. Phytopathology 84:462-468.

Brow, M. A. D., Oldenburg, M., Lyamichev, V., Heisler, L., Grotelueschen, J., Lyamichev, N., Kozyavkin, S., Fors, L., Dahlberg, J., Smith, L., and Olive, D. M. 1996. Mutation detection by Cleavase fragment length polymorphism analysis. Focus (Gibco Life Technologies) 18:2-5.

Cao, H., Bowling, S. A., Gordon, A. S., and Dong, X. 1994. Characterization of an Arabidopsis mutant that is nonresponsive to inducers of systemic acquired resistance. Plant Cell 6:1583-1592.

Century, K. S., Holub, E. B., and Staskawicz, B. J. 1995. NDR1, a locus of Arabidopsis thaliana that is required for disease resistance to both a bacterial and a fungal pathogen. Proc. Natl. Acad. Sci. USA 92:6597-6601.

Century, K. S., Lagman, R. A., Adkisson, M., Morlan, J., Tobias, R., Schwartz, K., Smith, A., Love, Jaime, Ronald, P. C., and Whalen, M. C. 1999. Developmental control of Xa21-mediated disease resistance in rice. Plant J. 20:231-236.

Century, K. S., Shapiro, A. D., Repetti, P. P., Dahlbeck, D., Holub, E., and Staskawicz, B. J. 1997. NDR1, a pathogen-induced component required for Arabidopsis disease resistance. Science 278:1963-1965.

Chin, D. B., Arroyo-Garcia, R., Ochoa, O., Kesseli, R. V., Lavelle, D. O., and Michelmore, R. W. 2001. Recombination and spontaneous mutation at the major cluster of resistance genes in lettuce (Lactuca sativa). Genetics 157:831-849.

Collins, N., Drake, J., Ayliffe, M., Sun, Q., Ellis, J., Hulbert, S., and Pryor, T. 1999. Molecular characterization of the maize $R p 1-D$ resistance haplotype and its mutants. Plant Cell 11:1365-1376.

Crute, I. R., and Johnson, A. G. 1976. The genetic relationship between races of Bremia lactucae and cultivars of Lactuca sativa. Ann. Appl. Biol. 83:125-137.

Dangl, J. L., Dietrich, R. A., and Richberg, M. A. 1996. Death don't have no mercy: cell death programs in plant-microbe interactions. Plant Cell 8:1793-1807.

Delaney, T., Friedrich, L., and Ryals, J. 1995. Arabidopsis signal transduction mutant defective in chemically and biologically induced disease resistance. Proc. Natl. Acad. Sci. U.S.A. 92:6602-6606.

Dietrich, R. A., Delaney, T. P., Uknes, S. J., Ward, E. R., Ryals, J. A., and Dangl, J. L. 1994. Arabidopsis mutants simulating disease resistance responses. Cell 77:565-577.

Dixon, M. S., Golstein, C., Thomas, C. M., van der Biezen, E. A., and Jones, J. D. 2000. Genetic complexity of pathogen perception by plants: the example of $R c r 3$, a tomato gene required specifically by $C f-2$. Proc. Natl. Acad. Sci. U.S.A. 97:8807-8814

Ellis, J., Dodds, P., and Pryor, T. 2000. Structure, function and evolution of plant disease resistance genes. Curr. Opin. Plant Biol. 3:278-284.

Falk, A., Feys, B. J., Frost, L. N., Jones, J. D. G., Daniels, M. J., and Parker, J. E. 1999. EDS1, an essential component of $R$ gene-mediated disease resistance in Arabidopsis has homology to eukaryotic lipases. Proc. Natl. Acad. Sci. U.S.A. 96:3292-3297.

Farrara, B. F., Ilott, T. W., and Michelmore, R. W. 1987. Genetic analysis of factors for resistance to downy mildew (Bremia lactucae) in species of lettuce (Lactuca sativa and L. serriola). Plant Pathol. 36:499-514.

Farrara, B. F., and Michelmore, R. W. 1987. Identification of new sources of resistance to downy mildew in Lactuca spp. Hortic. Sci. 22:647-649.

Feys, B. J., and Parker, J. E. 2000. Interplay of signaling pathways in plant disease resistance. Trends Genet. 16:449-455.

Freialdenhoven, A., Scherag, B., Hollricher, K., Collinge, D. B., ThordalChristensen, H., and Schulze-Lefert, P. 1994. Nar-1 and Nar-2, two loci required for $M l a_{12}$-specified race-specific resistance to powdery mildew in barley. Plant Cell 6:983-994.

Glazebrook, J. 1999. Genes controlling expression of defense responses in Arabidopsis. Curr. Opin. Plant Biol. 2:280-286.

Glazebrook, J., Zook, M., Mert, F., Kagan, I., Rogers, E. E., Crute, I. R., 
Holub, E. B., Hammerschmidt, R., and Ausubel, F. M. 1997. Phytoalexin-deficient mutants of Arabidopsis reveal that PAD4 encodes a regulatory factor and that four $P A D$ genes contribute to downy mildew resistance. Genetics 146:381-392.

Graham, M. A., Marek, L. F., Lohnes, D., Cregan, P., and Shoemaker, R. C. 2000. Expression and genome organization of resistance gene analogs in soybean. Genome 43:86-93.

Hammond-Kosack, K. E., Jones, D. A., and Jones, J. D. G. 1994. Identification of two genes required in tomato for full Cf-9-dependent resistance to Cladosporium fulvum. Plant Cell 6:361-374.

Hammond-Kosack, K. E., and Jones, J. D. G. 1997. Plant disease resistance genes. Annu. Rev. Plant Physiol. Plant Mol. Biol. 48:575-607.

Hu, G., Richter, T. E., Hulbert, S. H., and Pryor, T. 1996. Disease lesion mimicry caused by mutations in the rust resistance gene $r p 1$. Plant Cell $8: 1367-1376$

Hulbert, S. H., Webb, C. A., Smith, S. M., and Sun, Q. 2001. Resistance gene complexes: Evolution and utilization. Annu. Rev. Phytopathol. 39:285-312

Ilott, T. W., Hulbert, S. H., and Michelmore, R. W. 1989. Genetic analysis of the gene-for-gene interaction between lettuce (Lactuca sativa) and Bremia lactucae. Phytopathology 79:888-897.

Innes, R. W. 1998. Genetic dissection of R-gene signal transduction pathways. Curr. Opin. Plant Biol. 1:229-304.

Johal, G. S., Hulber, H. S., and Briggs, S. P. 1995. Disease lesion mimic mutations of maize: A model for cell death in plants. Bioessays 17:685-692.

Johnson, A. G., Laxton, S. A., Crute, I. R., Gordon, P. L., and Norwood, J. M. 1978. Further work on the genetics of race-specific resistance in lettuce (Lactuca sativa) to downy mildew (Bremia lactucae). Ann. Appl. Biol. 89:257-264.

Jones, D., and Jones, J. D. G. 1997. The role of leucine-rich repeat proteins in plant defenses. Adv. Bot. Res. Adv. Plant Pathol. 24:89-167.

Jones, J. D. 2001. Putting knowledge of plant disease resistance genes to work. Curr. Opin. Plant Biol. 4:281-287.

Kanazin, V., Marek, L. F., and Shoemaker, R. C. 1996. Resistance gene analogs are conserved and clustered in soybean. Proc. Natl. Acad. Sci. U.S.A. 93:11746-11750.

Kesseli, R. V., Witsenboer, H., Stanghellini, M., Vandermark, G., and Michelmore, R. W. 1993. Recessive resistance to Plasmopara lactucaeradicis maps by bulked segregant analysis to a cluster of dominant disease resistance genes in lettuce. Mol. Plant-Microbe Interact. 6:722-728.

Kesseli, R. V., Paran, I., and Michelmore, R. W. 1994. Analysis of a detailed genetic linkage map of Lactuca sativa (lettuce) constructed from RFLP and RAPD markers. Genetics 136:1435-1446.

Kobe, B., and Deisenhofer, J. 1994. The leucine-rich repeat: a versatile binding motif. Trends Biochem. Sci. 19:415-421.

Leister, D., Ballvora, A., Salamini, F., and Gebhardt, C. 1996. A PCRbased approach for isolating pathogen resistance genes from potato with potential for wide application in plants. Nat. Genet. 14:421-429.

Maisonneuve, B., Bellec, Y., Anderson, P., and Michelmore, R. W. 1994 Rapid mapping of two genes for resistance to downy mildew from $\mathrm{Lac}$ tuca serriola to existing clusters of resistance genes. Theor. Appl. Genet. 89:96-104.

Meyers, B. C., Chin, D. B., Shen, K. A., Sivaramakrishnan, S., Lavelle, D O., Zhang, Z., and Michelmore, R. W. 1998a. The major resistance gene cluster in lettuce is highly duplicated and spans several megabases. Plant Cell 10:1817-1832.

Meyers, B. C., Dickerman, A. W., Michelmore, R. W., Sivaramakrishnan, S., Sobral, B. W., and Young, N. D. 1999. Plant disease resistance genes encode members of an ancient and diverse protein family within the nucleotide-binding superfamily. Plant J. 20:317-332.

Meyers, B. C., Shen, K. A., Rohani, P., Gaut, B. S., and Michelmore, R. W. 1998b. Receptor-like genes in the major resistance locus of lettuce are subject to divergent selection. Plant Cell 10:1833-1846.

Michelmore, R. W., Marsh, E., Seeley, S., and Landry, B. S. 1987. Transformation of lettuce mediated by Agrobacterium tumefaciens. Plant Cell Rep. 6:439-442.

Michelmore, R. W., and Meyers, B. C. 1998. Clusters of resistance genes in plants evolve by divergent selection and a birth-and-death process. Genome Res. 8:1113-1130.

Okubara, P. A., Anderson, P. A., Ochoa, O. E., and Michelmore, R. W. 1994. Mutants of downy mildew resistance in Lactuca sativa (lettuce). Genetics 137:867-874.

Okubara, P. A., Arroyo-Garcia, R., Shen, K. A., Mazier, M., Meyers, B. C., Ochoa, O. E., Kim, S., Yang, C.-H., and Michelmore, R. W. 1997. A transgenic mutant of Lactuca sativa (Lettuce) with a T-DNA tightly linked to loss of downy mildew resistance. Mol. Plant-Microbe Interact. 10:970-977.

Oldroyd, G. D., and Staskawicz, B. J. 1998. Genetically engineered broadspectrum disease resistance in tomato. Proc. Natl. Acad. Sci. USA 95:10300-10305.
Paran, I., Kesseli, R. V., and Michelmore, R. W. 1991. Identification of RFLP and RAPD markers to downy mildew resistance genes in lettuce with near isogenic lines. Genome 35:1021-1027.

Parker, J. E., Coleman, M. J., Szabo, V., Frost, L. N., Schmidt, R., van der Biezen, E. A., Moores, T., Dean, C., Daniels, M. J., and Jones, J. D. G. 1997. The Arabidopsis downy mildew resistance gene RPP5 shares similarity to the Toll and interleukin-1 receptors with $N$ and L6. Plant Cell 9:879-894.

Parker, J. E., Holub, E. B., Frost, L. N., Falk, A., Gunn, N. D., and Daniels, M. J. 1996. Characterization of eds 1, a mutation in Arabidopsis suppressing resistance to Peronspora parasitica specified by several different RPP genes. Plant Cell 8:2033-2046.

Parniske, M., Hammond-Kosack, K. E., Golstein, C., Thomas, C. M. Jones, D. A., Harrison, K., Wulff, B. B. H., and Jones, J. D. G. 1997. Novel disease resistance specificities result from sequence exchange between tandemly repeated genes at the $C f-4 / 9$ locus of tomato. Cell 91:821-832.

Peterhansel, C., Freialdenhoven, A., Kurth, J., Kolsch, R., and SchulzeLefert, P. 1997. Interaction analyses of genes required for resistance responses to powdery mildew in barley reveal distinct pathways leading to leaf cell death. Plant Cell 9:1397-1409.

Richberg, M. H., Aviv, D. H., and Dangl, J. L. 1998. Dead cells do tell tales. Curr. Opin. Plant Biol. 1:480-485.

Salmeron, J. M., Barker, S. J., Carland, F. M., Mehta, A. Y., and Staskawicz, B. J. 1994. Tomato mutants altered in bacterial disease resistance provide evidence for a new locus controlling pathogen recognition. Plant Cell 6:511-520.

Salmeron, J. M., Oldroyd, G. E. D., Rommens, C. M. T., Scofield, S. R., Kim, H. S., Lavelle, D. T., Dahlbeck, D., and Staskawicz, B. J. 1996. Tomato $\mathrm{Prf}$ is a member of the leucine-rich repeat class of plant disease resistance genes and lies embedded within the Pto kinase gene cluster Cell 86:123-133.

Sambrook, J., Fritisch, E. F., and Maniatis, T. 1989. Molecular Cloning: A Laboratory Manual, 2nd ed. Cold Spring Harbor Laboratory Press, Cold Spring Harbor, NY.

Schulze-Lefert, P., Peterhaensel, C., and Freialdenhoven, A. 1997. Mutation analysis for the dissection of resistance. Pages 45-64 in: The Genefor-Gene Relationship in Plant-Parasite Interactions. I. R. Crute, E. B. Holub, and J. J. Burdon, eds. CAB International, Wallingford, U.K

Shen, K. A., Meyers, B. C., Islam-Faridi, M. N., Chin D. B., Stelly, D. M., and Michelmore, R. W. 1998. Resistance gene candidates identified using PCR with degenerate primers map to resistance gene clusters in lettuce. Mol. Plant-Microbe Interact. 11:815-823.

Sicard, D., Woo, S.-S., Arroyo-Garcia, R., Ochoa, O., Nguyen, D., Korol, A., Nevo, E., and Michelmore, R. W. 1999. Molecular diversity at the major cluster of disease resistance genes in cultivated and wild Lactuca spp. Theor. Appl. Genet. 99:405-418.

Speulman, E., Bouchez, D., Holub, E. B., and Beynon, J. L. 1998. Disease resistance gene homologs correlate with disease resistance loci of Arabidopsis thaliana. Plant J. 14:467-74.

Tang, X., Xie, M., Kim, Y. J., Zhou, J., Klessig, D. F., and Martin, G. B. 1999. Overexpression of Pto activates defense responses and confers broad resistance. Plant Cell 11:15-29.

Tao, Y., Yuan, F., Leister, R. T., Ausubel, F. M., and Katagiri, F. 2000. Mutational analysis of the Arabidopsis nucleotide binding site-leucine rich repeat resistance gene RPS2. Plant Cell 12:2541-2554.

Walbot, V., Hosington, D. A., and Neuffer, M. G. 1983. Disease lesion mimic mutants. Pages 431-442 in: Genetic Engineering of Plants. T. Kosuge, C. P. Meredith, and A. Hollaender, eds. Plenum Press, New York.

Wang, Z.-X., Yano, M., Yamanouchi, U., Iwamoto, M., Monna, L., Hayasaka, H., Katayose, Y., and Sasaki, T. 1999. The Pib gene for rice blast resistance belongs to the nucleotide binding and leucine-rich repeat class of plant disease resistance genes. Plant J. 19:55-64.

Warren, R. F., Merritt, P. M., Holub, E., and Innes, R. W. 1999. Identification of three putative signal transduction genes involved in $R$ genespecified disease resistance in Arabidopsis. Genetics 152:401-412.

Witsenboer, H., Kesseli, R. V., Fortin, M., Stanghellini, M., and Michelmore, R. W. 1995. Sources and genetic structure of a cluster of genes for resistance to three pathogens in lettuce. Theor. Appl. Genet. 91:178-188.

Yang, C.-H., Ellis, J. G., and Michelmore, R. W. 1993. Infrequent transposition of Ac in lettuce, Lactuca sativa. Plant Mol. Biol. 22:793-805.

Yoshimura, S., Yamanouchi, U., Katayose, Y., Toki, S., Wang, Z.-X., Kono, I., Kurata, N., Yano, M., Iwata, N., and Sasaki, T. 1998. Expression of $X a 1$, a bacterial blight-resistance gene in rice, is induced by bacterial inoculation. Proc. Natl. Acad. Sci. U.S.A. 95:1663-1668.

Yu, Y. G., Buss, G. R., and Sagaimaroof, M. 1996. Isolation of a superfamily of candidate disease-resistance genes in soybean based on a conserved nucleotide-binding motif. Proc. Natl. Acad. Sci. U.S.A. 93:11751-11756 